\title{
Comparative study of biochemical composition and sensory characteristics of salt and garlic treated smoke-dried Chapila (Gudusia chapra, Hamilton; 1822) and Guchi Baim (Mastacembelus pancalus, Hamilton-Buchanan; 1822) stored at refrigeration temperature $\left(4^{0} \mathrm{C}\right)$
}

\author{
Mosarrat Nabila Nahid ${ }^{* 1}$, Dr. Gulshan Ara Latifa ${ }^{1}$, Dr. Subhash Chandra \\ Chakraborty $^{2}$, Farzana Binte Farid ${ }^{1}$ and Mohajira Begum ${ }^{3}$ \\ ${ }^{1}$ Department of Zoology, University of Dhaka, Dhaka 1000, Bangladesh \\ ${ }^{2}$ Department of Fisheries Technology, Bangladesh Agricultural University, Mymensingh, Bangladesh \\ ${ }^{3}$ Institute of food Science and Technology, BCSIR, Dhaka-1205, Bangladesh.
}

\begin{abstract}
To minimize the loss of spoilage, the most perishable food item (ex-fish) different types of processing and preservation method like smoking have been introduced and practiced throughout the world including Bangladesh. The aim of this study is to investigate the effects of natural preservatives such as salt and garlic on the shelf-life of smoke-dried commercially important freshwater fish species in Bangladesh viz., Chapila and Guchi Baim fish product and to analyzed biochemical composition and sensory qualities storage at refrigeration temperature $\left(4^{0} \mathrm{C}\right)$. During storage, moisture and TVB-N were increased significantly $(p<0.05)$ ranged from 6.77-10.12\% and 4.09-20.14 $\mathrm{mgN} / 100 \mathrm{gm}$ in case of salt and garlic $(S+G)$ treated chapila (21month) and 7.53-8.70\% and 5.74-18.92 mgN/100gm in case of $S+G$ Guchi Baim (24 month) respectively. The percentage of protein, fat and ash content were decreased significantly $(p<0.05)$ varied from $45.24-42.54 \%$ , 30.52-28.94 \% and 18.71-16.45\% in case of $S+G$ chapila (21 month) and 59.07-58.59\%, 11.32-10.77\% and $22.15-21.48 \%$ in case of $S+G$ Guchi Baim (24 month) respectively. There was a general decline in sensory characteristics i.e. color, texture, odor, general appearance and mean of acceptability of fish-product during storage. From the overall performance, smoke-dried $S+G$ Guchi Baim have better shelf-life.
\end{abstract}

Key words: Smoke-drying, biochemical-composition, chapila, Guchi-Baim, salt-garlic.

\section{Introduction}

The country Bangladesh abounds in a large variety of fish species [1]. Fish is a key ingredient on the global menu, a vital factor in the global environment and an important basis for livelihood worldwide [2]. Fish is also widely acceptable because of its high palatability, low cholesterol and tender flesh [3]. Fresh, but more often smoked-dried or oven powdered fish is a critical source of dietary protein and micronutrients for many isolated communities in rural areas [4]. Fish is one of the most perishable staples; it spoils very quickly because of intrinsic and extrinsic factors. The high ambient temperature in the tropics hastens fish spoilage by accelerating the activities of bacteria, enzymes and chemical oxidation of fat in fresh fish [3]. Unfortunately, post harvest losses have been estimated at 20-50\% in the tropical countries [3]. This level of post harvest losses could be very significant especially in this period of fish scarcity and escalating prices and could have negative impact on the national food security. In view of the fact that post harvest spoilage has contributed immensely to the poor supply of fish protein to the Bangladeshi populace, the need to preserve fish for better shelf-life, good flavor as well as creation of employment opportunities becomes imperative.

Fish spoilage is a metabolic process that causes fish to be undesirable for human consumption due to changes in sensory and nutritional characteristics. Thus processing and preservation of fresh fish were utmost importance to maintain product quality, reduce wastage and prevent economic losses [5]. Methods of fish preservation include freezing, smoking, canning, sun-drying etc [6]. Smoke curing method is a method which is not affected by climatic condition. It also has worldwide acceptability as process fish food. Smoking is the oldest and most common method of fish preservation in many developing countries [7]. Smoke-dried fish is a traditional part of the diet of a large section of the world's population and it is relished for its appetizing flavor and taste [8].

Fresh water fish constitute an important part of fish distribution in Bangladesh and the marketing trends predict an increase in consumer demands. Preservation of fish generally slows down spoilage. Preservation

* To whom communication should be made, e-mail: mnabilanahid@yahoo.com 
methods are applied with an intention of making the fish safer and extend its shelf-life [9]. Many fish species have very good preservation qualities after salting, sun drying and even smoking [10]. Smoking method mostly imparts a desirable flavor and in hibits the growth of microbe [11]. In this experiment we used common fresh water lean fish Chapila and Guchi Baim which has unique test.

Small indigenous fishes like Chapila and Guchi Baim have been considered as an excellent source of essential animal protein, as they are eaten whole have a very high content of bioavailability calcium, vitamin-A, Iron and Zinc which can play an important role in the elimination of malnutrition problem in Bangladesh. Much attention is being directed at fresh water small indigenous fishes because of its health benefits, as a result of the presence of omega-3-fatty acids in the fish oil $[12,13]$. The reduction of these losses can only be achieved by systematic improvements in handling, processing, storage and distribution [14].

Considerable work has been done on smoked large fish species such as smoked thai pangus, smoked Ilish, smoked Tilapia but no serious attempt has yet been made to preserve smoke-dried lean fishes.

In Bangladesh smoked fish is recent addition to the fishery products. Fish is normally salted before smoking. Different salting methods are being practiced by the smoked fish industry in different parts of the world $[15,16]$. But in this research salt \& garlic used before smoking which is easily available and cheaper cost wise. Garlic is widely used as curing agents in a variety of food products. Garlic (Allium sativum) exhibit antioxidative activities and inhibit the microbial growth in a variety of foods $[17,18]$. The active compound present in garlic is the allicin, allyl alcohol which is a thiosuffinate compound reported for its anti-microbial activity [19].

Thus, this research is aimed at studying the effectiveness of fresh salt and garlic on extending the shelflife by analysis biochemical composition (proximate and chemical composition) and sensory score value.

\section{Materials and methods}

2.1. Sample collection: Two freshwater fish species; Chapila (Gudusia chapra) and Guchi Baim (Mastacembelus pancalus) was collected from the Meghna River early in the morning. Fresh mature fish samples were transported to laboratory in sterile polythene to avoid any type of microbial contamination. This study was conducted between October 2011 to January 2014 at the Fish Technology Section of the Institute of Food Science and Technology (IFST) of Bangladesh Council of Scientific and Industrial Research (BCSIR), Dhanmondi, Dhaka.

2.2. Preparation of Sample: At first, the collected Chapila fish was discaled while Guchi Baim fish was beheaded. Then both fishes were gutted and washed properly with clean water. The dressed fish samples were then weighed and prepared for further processing.

2.3. Preparation of samples for processing: The dressed fish samples were then dip in freshly prepared $30 \%$ salt and 30\% garlic solution for 15 minutes followed by draining.

2.4. Fish smoke-drying: The fishes were smoked in improved traditional type of smoking kiln [20]. The fish smoking kiln was operated by first loading tamarind wood chips and rice-husk into the heat chamber, preheating for some minutes and then loading the fish-samples onto removable wire mesh trays in its central chamber for the smoking process. The desired temperature $\left(75-80^{\circ} \mathrm{C}\right)$ was maintained manually. Smoking was done approximately for 4 hours. During the smoking fish samples were turned upside down in the middle period, to make the sample smooth and steady in texture and appearance. The smoked fishes showed characteristic attractive golden brown color and acceptable texture with smoky flavor, which was followed by cooling for 2030 minutes at ambient temperature to make fish muscle compressed and facilitate to prevent breaking of smoked products. The cooled smoked fish samples were then packed and sealed in vacuum condition with marking taken in two different polythene bags (transparent). Two groups of smoke-dried fish product were then kept for storage at refrigerator temperature for further analysis of sensory and biochemical compositions.

During the storage period the two types of smoke-dried fish samples were checked on three month interval basis.

2.5. Biochemical analysis: Analytical methods were applied for the determination of sensory and biochemical composition of the processed fish products on experimental basis. The analytical methods are given below:

$>$ Physical changes were assessed by the sensory method. Parameters on the questionnaires were as follows: (Like extremely $=9$; Like very much $=8$; Like moderately $=7$; Like slightly $=6$; Neither like nor dislike $=$ 5; Dislike slightly $=4$; Dislike moderately $=3$; Dislike very much $=2$; and Dislike extremely $=1$ ) [21].

$>$ Moisture, fat and ash contents of the fish were determined by AOAC method [22].

$>$ The crude protein of the fish was determined by Micro-Kjeldhal method [23].

$>$ Chemical changes were studied by determining the TVB-N using Conway modified micro-diffusion technique [24]. 


\section{Statistical analysis}

To calculate significance at $\mathrm{p}<0.05$ level all data was analyzed with the help of SPSS for windows, version 20 statistical software.

\section{Results and Discussion}

Moisture, protein, fat, ash and TVB-N of fresh Chapila fish was $76.41 \%, 10.53 \%, 11.62 \%, 1.50 \%$ and $2.40 \mathrm{mgN} / 100 \mathrm{~g}$ and Guchi Baim fish was $77.21 \%, 15.17 \%, 6.13 \%, 1.72 \%$ and $3.16 \mathrm{mgN} / 100 \mathrm{~g}$ respectively (Fig. 1). Fresh sample presented low protein content [25].

3.1. Sensory score value: Sensory methods are considered to be the most useful and dependable criteria for assessing the degree of freshness for quality determination. Human being is capable to detect defects from visual signs of deterioration such as loss of freshness and changes during storage period. Sensory quality assessment is an easy, quick and efficient method of getting idea about the quality of the product. This method is based on the response or tendency of sense organ for accepting the food products.

The quality assessment as well as sensory evaluation (score) was carried out every three months intervals for samples stored at refrigeration temperature $\left(4^{0} \mathrm{C}\right)$ using trained panel of four judges following 9point ascending scale to evaluate changes in color, odor, texture, general appearance and mean of general acceptability until it was an acceptable condition.[26].

The shelf-life of these two types of smoke-dried fish product was found to be related to the temperature and the length of storage. At the beginning of storage all the sensory parameters of these two samples were rated as good based on the grading scale. The highest mean of general acceptability score was found 8.87 in case of Chapila and 8.85 in case of Guchi Baim fish. The mean of general acceptability score decreased as storageduration increased. In this study the shelf-life of smoke-dried Chapila and Guchi Baim fish was 21 and 24 month. The mean of general acceptability score of the end product of smoke-dried Chapila and Guchi Baim was 3.65 (21 month) and 3.54 (24 month) respectively. At the end of 24 month smoke-dried Chapila fish product became spoiled (3.33) whereas smoke-dried Guchi Baim was still remain in good condition (Table-1). The Guchi Baim fish product was spoiled at the end of 27 month (3.35). This agrees with the results of research into storage of smoke dried fish [27] and crustaceans (Oyster and shrimps) [28, 29] which revealed quality loss during storage both at ambient temperature and chilling.

3.2. Proximate analysis: During smoke-drying, the percentage of moisture content decreased and protein, lipid and ash content increased significantly $(\mathrm{p}<0.05)$ due to water loss. This observation is in agreement with the findings of Atlantic mackerel and European eel, pike perch and rainbow trout. [30, 31].

3.2.1. Moisture (\%) content: The moisture content can be used as a pointer to the rate at which deterioration occurred in fish samples resulting in the early decomposition. During storage at refrigeration temperature, percent of moisture were found to vary from $6.77 \%$ (o day) to $10.12 \%$ (21 month) for salt- garlic treated smoke-dried Chapila and $7.53 \%$ (o day) to $8.70 \%$ (24 month) for salt-garlic treated smoke-dried Guchi Baim fish respectively (Fig. 2 and Fig. 3). There was a gradual increase in the moisture content of this two types of salt- garlic treated smoke-dried fish samples with increasing storage period. The gutted smoke dried fish samples of African cat fish (Clarias nigrodigitus) had moisture content as 6.27 to $10.92 \%$ which is similar with present study [32]. Moisture content of $12 \%$ is the level beyond which fish products begin to grow moulds after few days [33]. In this study the final moisture of salt- garlic treated smoke-dried fish samples was less than $12 \%$.

3.2.2. Protein $(\%)$ content: Significant increased in protein levels $(p<0.05)$ in both smoke-dried fish when compared with the fresh fish, suggested that protein nitrogen was not lost during smoke-drying [34, 35].

Protein decomposes with passing time [36]. Protein (\%) were found to vary from $45.24 \%$ (o day) to $42.54 \%$ (21 month) for salt-garlic treated smoke-dried Chapila and $59.07 \%$ (o day) to $58.59 \%$ (24 month) for salt-garlic treated smoke-dried Guchi Baim respectively (Fig. 2 and Fig. 3). In storage condition, the protein content decreased significantly with the time due to water soluble protein diffused out to the surrounding for exosmosis [37]. This could be due to gradual degradation of initial crude protein to more volatile products such as total volatile bases, hydrogen sulphide and ammonia [3]. Similar drop in protein concentration was reported for Heterobranchus longifilis [38].

3.2.3. Fat (\%) content: Fat (\%) were found to vary from $30.52 \%$ (o day) to $28.94 \%$ (21 month) for salt-garlic treated smoke-dried Chapila and $11.32 \%$ (o day) to $10.77 \%$ (24 month) for salt-garlic treated smoke-dried Guchi Baim respectively (Fig. 2 and Fig. 3). Usually moisture and fat contents in fish flesh are inversely related and there sum is approximately $80 \%$ [39]. This inverse relationship was also well defined in this experiment.

3.2.4. Ash (\%) content: Ash (\%) was found to vary from $18.71 \%$ (o day) to $16.45 \%$ (21 month) for salt-garlic treated smoke-dried Chapila and $22.15 \%$ (o day) to $21.48 \%$ (24 month) for salt-garlic treated smoke-dried Guchi Baim respectively (Fig. 2 and Fig. 3). The ash content changes with the time of storage due to absorbance of moisture and loss of protein [37]. Smaller sized fish species has higher ash content due to the higher bone of flesh ratio [40]. 
Comparative study of biochemical composition and sensory characteristics of salt and garlic ....

During storing at refrigeration temperature, after 21 month it was found that the salt-garlic treated smoke-dried Chapila fish product was spoiled while the salt- garlic treated Guchi Baim fish were found to be in their normal characteristics up to the 24 months. Because of antifungal effect of garlic, there is no fungal attack shown on salt-garlic treated smoke-dried Chapila and Guchi Baim fish product.

Significant statistical differences were found between the initial product and end product $(\mathrm{P}<0.05)$ after storage period.

3.3. TVB-N value: It was observed that spoilage of fish flesh resulted from the action of enzymes and bacteria; this can be slowed down through the application of salt and removal of moisture to increase the shelf life of fish. Total Volatile base Nitrogen (TVB-N) is widely used as an indicator of the degree of lipid oxidation [41]. It helps to measure the level of fish spoilage and to explore the shelf life of fish. During storage period total volatile base nitrogen value (TVB-N) increased. In salt-garlic treated smoke-dried Chapila fish product, the TVB-N values ranges from 4.09 (0 day) to $20.14 \mathrm{mgN} / 100 \mathrm{~g}$ (21 month) whereas ranges of TVB-N value was 5.74 (0 day) to 18.92 (24 month) $\mathrm{mgN} / 100 \mathrm{~g}$ in salt-garlic treated smoke-dried Guchi Baim fish product respectively (Fig. 4). Pearson recommended that the limit of acceptability of fish is 20-30mg N per 100g [42]. While Kirk and Sawyer suggested a value of 30-40mg N/100g as the upper limit [43]. Increase in final values of TVB-N in this study is similar with other researchers $[38,44]$. During hot smoking fish are exposed to heat and atmospheric oxygen. These factors can accelerate the oxidation of the fish lipids resulting in an increased in TBA [45].

\section{Conclusion}

The present study demonstrates the efficacy of salt and garlic solution as a potent antibacterial and antioxidant agent that can be used for the preservation and shelf-life extension of fish products. The improvement and development of packaging and good storage condition (refrigeration temperature) will protect the smoke-dried products against spoilage.

\section{Acknowledgements}

The author acknowledges the scientist and technicians of BCSIR, Dhaka, Bangladesh for their technical help.

\section{References}

[1]. DoF, 2008. Matshaw Sampad Unnayan Avijan (in Bengali). Department of Fisheries, Ministry of Fisheries and Livestock, Dhaka, Bangladesh. pp. 11-82

[2]. Bene, C. and Heck, S. 2005. Fish and Food Security in Africa. NAGA, World Fish. Centre quarterly vol. 28. no 3 and 4 July December.

[3]. Eyo, A. A. 2001. Fish processing technology in the tropics, University of Ilorin Press. 403pp

[4]. Anon, 2000. Communication from the commission to the counciland the parliament. Con (2000) 724, Brussade European commission, 20pp.

[5]. Olley, J. Doe, P.E. and Heruwat, E.S. 2000. The Influence of Drying and Smoking on the Nutritional properties of Fish: An introductory Overview. In International Union Nutritional Sciences Conf. Malaysia (2000) Pp 1-6.

[6]. Eyo, A.A. 1992. The nutritive value of Traditionally prepared fish meals. FAO Fisheries report No. 467, Sup 147-149.

[7]. Kumolu-Johnson, N.F. Aladetohun, C.A. Ndimele, A. 2010. The effect of smoking on the nutrient composition of the African cat fish (Clarias gariepinus) African Journal of Biotechnology, 9, 73-76.

[8]. Kiin-Kabari, D.B. Barimalaa, I.S. Achinewhu, S.C. Adeniji, T.A. 2011. Effects of extract from three indigenous spices on the chemical stability of smoke-dried cat fish (Clarias lezera) during storage. African journal of food, Agriculture, Nutrition and Development, 11(6), 5335-5343.

[9]. Ghazala, S. 1994. New packaging technology for seafood preservation,shelf-life extension and pathogen control. In fisheries processing Biotechnological Applications (Ed. Am .Marthin). Chapman and Hall, London pp. 83-110.

[10]. Madu, C.T. Okoye, F.E. Sado, E.K. Omorinkoba, W.S. Bankole, W.O. and Ita, E.O. 1984. A preliminary report of induced breeding trials with the mud fish (Clarias anguillaris) KLRI Animal Report.144-159.

[11]. Swastawati, F. 2000. The Effect of Different Smoking Method on the Omega-3 Fatty Acid Composition of Tuna (Euthymus sp.) J. of Coast Dev.3(3), hal 615-622.

[12]. Vileg, P. Body, D.R. 1988. Lipid content and fatty acid composition of some New-Zealand fish. NZJ Marine Fresh water Res.: $22: 151$.

[13]. Negbenebor, C.A. 1990. Raw material supply for fish and animal processing Industries. In Proceedings of a workshop organized by the N/E Chapter of NIFST, Maiduguri, Nigeria. pp12-24. Eds. I. Nkama and P. Sopade.

[14]. FAO/WHO. 1990. Protein quality evaluation. In: Report of A joint FAO/WHO Expart Consultations. FAO of The United Nations, Rome.40pp

[15]. Espe, M. Nortvedt, R. Lie, O. and Hafsteinsson, H. 2001. Atlantic salmon (Salmo salar), as raw material for smoking industry. 1: effect of different salting methods on the oxidation of lipids. Food Chem. 75(4): 411-416.

[16]. Jittinandana, S. Kenney, P.B. Slider, S.D. and Kser, R.A. 2002. Effect of brining concentration and brining time on quality of smoked rainbow trout fillets. J. Food Sci.67 (6): 2095-2059.

[17]. Al-Jalay, B. G. Blank, B. Connell, M.C. and Kl-Khayat, M. 1987. Antioxidant activity of selected spices used in fermented meat sausage. J. Food Protect., 50, 25-27.

[18]. Jurdi-Haldeman, D. J. Neil, H. Mc and Yared, D.M. 1987. Antioxidant activity of onion and garlic juices in stored cooked ground lamb. J. Food Protect., 50, 411-413.

[19]. Chung, S.H. Kwon, S. Shim, T. and Kyung, K.H. 2007. Journal of food science, 72, M434-M440.

[20]. Sarkar, 2005. A study on the shelf-life of smoked thai pangus (Pangasius hypophthalmus). M.Sc. Thesis submitted to Bangladesh Agricultural University, Mymensingh, pp.71 
Comparative study of biochemical composition and sensory characteristics of salt and garlic ....

[21]. Larmond, E. 1977. Laboratory methods for sensory evaluation of food. Research Branch, Canada Dept. of Agriculture Publication 1637.

[22]. AOAC, 1990. Official method of analysis. Association of Official Agricultural Chemists W. Horwitz (Editor) $12^{\text {th }}$ ED. Washington.

[23]. Pearson, D. 1999. Pearson's composition and analysis of foods. University of Reading .

[24]. Conway, E. J. and Byrne, A. 1933. Micro-diffusion analysis of TVN. Biochem. J. 27, 419-429.

[25]. Eyo, A.A.1998. Shelf-life of Moon fish (Citharinus citharus) and Tumk Fish (Mormyrus rume) During storage at ambient temperature and on Ice. FAO Fisheries Report No. 574:35-37.

[26]. Debnath, S.K. 2009. A study of the improved technique for the production of smoked Thai Pangas (Pangasius hypopthalmus). M.Sc. thesis. Bangladesh Agricultural University, Mymensingh. 32pp.

[27]. Daramola, J.A. Fasakin, E.O. Adeparusi, E.O. 2007. Changes in physicochemical and sensory characteristics of smoke-dried fish species stored at ambient temperature. African Journal of Food and Agriculture, Nutrition and Development. 7(6):169-183.

[28]. Llobreda, A.T. Bukalacao, M.L. Sunaz, N. 1986. Effects of Storage on the Microbial Quality of Slipper oyster (Cassostera iredalei). In: Maclean JL, Izon LBD, Hosilus LV (Eds). The First Asian Fisheries Forum, Manilla, Philippines.

[29]. Reilly, A.E. Dela-cruz, D. 1986. Post- harvest spoilage of shrimp (Penaeus monodon). In: Maclean JL, Dixon LB, Hossillus LV (Eds). The first Asian Fish Forum. Manilla, Phillipines.

[30]. Bhuiyan, A.K.M. Ratnayake, W.M.N. Acman, R.G. 1986. Effect of smoking on the proximate composition of Atlantic mackerel (Scomber scombrus). J. Food Sci. 51: 327-329.

[31]. Unlusayin, M. Kaleli, S. Gulyavuz, H. 2001. The determination of flesh productivity and protein components of some fish species after hot smoking. J. Sci. Food Agric. 81:661-664.

[32]. Faturoti, E.O. 1985. Biological utilization of sun-dried and smoked African Cat fish (Chrysichthys nigrodigitus). Nutritative Reports International, Rwp. of Wildlife and Fisheries Management, Univ. of Ibadan, Nigeria. 30 (6), 1395-1400.

[33]. FAO/APHCA. 1989. The use of palm-Kernel cake as Animal feed. FAO/APHCA Publication No. 8

[34]. Puwastien, P. Judprasong, K. Kettwan, E. Vasanachitt, K. Nakngamanong, Y. Bhattacharjee, L. 1999. Proximate composition of raw and cooked Thai Freshwater and Marine Fish. J. Food Composition Anal., 12:9-16.

[35]. Tao, W. Linchun, M. 2008. Influence of hot Air Drying and Microwave Drying on Nutritional and odorous Properties of Grass Carp (Ctenopharyngodon idellus) Fillets. Food Chem., 110(3):647-653.

[36]. Ghezala, S. 1994. "New Packaging Technology for Seafood Preservation Shelf Life Extension and Pathogen Control". In: Fisheries Processing Biotechnological Applications. A.M. Martin (ed.). Chapman Hall: London, UK. 83 -110.

[37]. Hassan, M.N. Rahman, M. Hossain, M.M. Nowsad, A.A.K.M. and Hossain, M.B. 2013. Post-Harvest Loss and Shelf Life of Traditionally Smoked Shrimp Products Produced in Bangladesh. World J. of Fish and Marine Sci. 5(1):14-19.

[38]. Abolagba, O.J. and Osifo, S.J. 2008. "The Effect of Smoking on the Chemical Composition and Keeping Qualities of Catfish Heterobranchus bidorsalis using Two Energy Sources". Journal of Agriculture, Forestry and Fisheries (JAFF). 5(1), 27-30.

[39]. FAO. 1999. World production of fish, crustaceans and mollusks by major fishing areas. Fisheries Information Data and Statistics unit (FIDI), Fisheries Department, FAO Rome., 33pp.

[40]. Daramola, J.A. Fasakin, E.A. Adeparusi, E.O. 2007. Changes in physicochemical and sensory characteristics of smoke-dried fish species stored at ambient temperature $.10 \mathrm{pp}$.

[41]. Daramola, J.A. Kester, C.T. and Allo, O.O. 2013. Biochemical evaluation of hot-smoked African catfish (C. gariepinus) sampled from Sango and Ota market in Ogun State. 382 pp.

[42]. Pearson, D. 1982. The Chemical Analysis of Foods. Churchill Livingstone, Edinburgh, London and New York.

[43]. Kirk, R.S. and Sawyer, R. 1991. Nitrogen Determination. Pearson's Composition and Analysis of Foods. Longman Scientific Publisher: London, UK. 29-36

[44]. Trinidad, L. M. and Estrada, M.H. 1986. "Effect of Raw Material Freshness on the Quality of Smoked Tilapia (Oreochromis niloticus)”. In: J.L. Maclean, L.B. Dixon, and L.V. Hosilus (eds.). The First Asian Fisheries Forum. Manilla, Philippines. 471-472.

[45]. Bilgin, F. Unlusayin, M. and Gunlu, A. 2008. "The Determination of the Shelf Life and Some Nutritional Components of Gilthead Seabream (Sparus aurata L., 1758) after Cold and Hot Smoking”. Turk. J. Vet. Anim. Sci.32(1):49-56.

Table-1. Sensory evaluation score of salt and garlic treated Smoke-dried Chapila and Guch Baim fish stored at refrigerator temperature.

\begin{tabular}{|c|c|c|c|c|c|c|}
\hline $\begin{array}{l}\text { Storage } \\
\text { (month) }\end{array}$ & Product & Color & Odor & Texture & $\begin{array}{l}\text { General } \\
\text { appearance }\end{array}$ & $\begin{array}{l}\text { Mean of general } \\
\text { acceptability }\end{array}$ \\
\hline \multirow[t]{2}{*}{0} & Chapila & 8.81 & 8.88 & 8.85 & 8.94 & 8.87 \\
\hline & Guchi Baim & 8.81 & 8.87 & 8.84 & 8.89 & 8.85 \\
\hline \multirow[t]{2}{*}{3} & Chapila & 7.86 & 7.75 & 7.79 & 7.89 & 7.82 \\
\hline & Guchi Baim & 7.74 & 7.78 & 7.76 & 7.81 & 7.77 \\
\hline \multirow[t]{2}{*}{6} & Chapila & 6.81 & 6.83 & 6.82 & 6.88 & 6.83 \\
\hline & Guchi Baim & 6.84 & 6.83 & 6.81 & 6.85 & 6.83 \\
\hline \multirow[t]{2}{*}{9} & Chapila & 5.69 & 5.65 & 5.71 & 5.77 & 5.70 \\
\hline & Guchi Baim & 6.34 & 6.38 & 6.33 & 6.47 & 6.38 \\
\hline \multirow[t]{2}{*}{12} & Chapila & 5.41 & 5.40 & 5.31 & 5.45 & 5.39 \\
\hline & Guchi Baim & 5.73 & 5.71 & 5.65 & 5.78 & 5.72 \\
\hline \multirow[t]{2}{*}{15} & Chapila & 4.65 & 4.71 & 4.63 & 4.75 & 4.68 \\
\hline & Guchi Baim & 5.38 & 5.40 & 5.33 & 5.47 & 5.39 \\
\hline \multirow[t]{2}{*}{18} & Chapila & 4.33 & 4.25 & 4.36 & 4.40 & 4.33 \\
\hline & Guchi Baim & 4.73 & 4.75 & 4.69 & 4.78 & 4.74 \\
\hline \multirow[t]{2}{*}{21} & Chapila & 3.62 & 3.60 & 3.68 & 3.71 & 3.65 \\
\hline & Guchi Baim & 4.34 & 4.32 & 4.35 & 4.42 & 4.36 \\
\hline \multirow[t]{2}{*}{24} & Chapila & 3.33 & 3.28 & 3.31 & 3.42 & 3.33 \\
\hline & Guchi Baim & 3.52 & 3.50 & 3.54 & 3.60 & 3.54 \\
\hline \multirow[t]{2}{*}{27} & Chapila & $*$ & $*$ & $*$ & $*$ & $*$ \\
\hline & Guchi Baim & 3.34 & 3.30 & 3.33 & 3.42 & 3.35 \\
\hline
\end{tabular}

$*=$ Rejected 


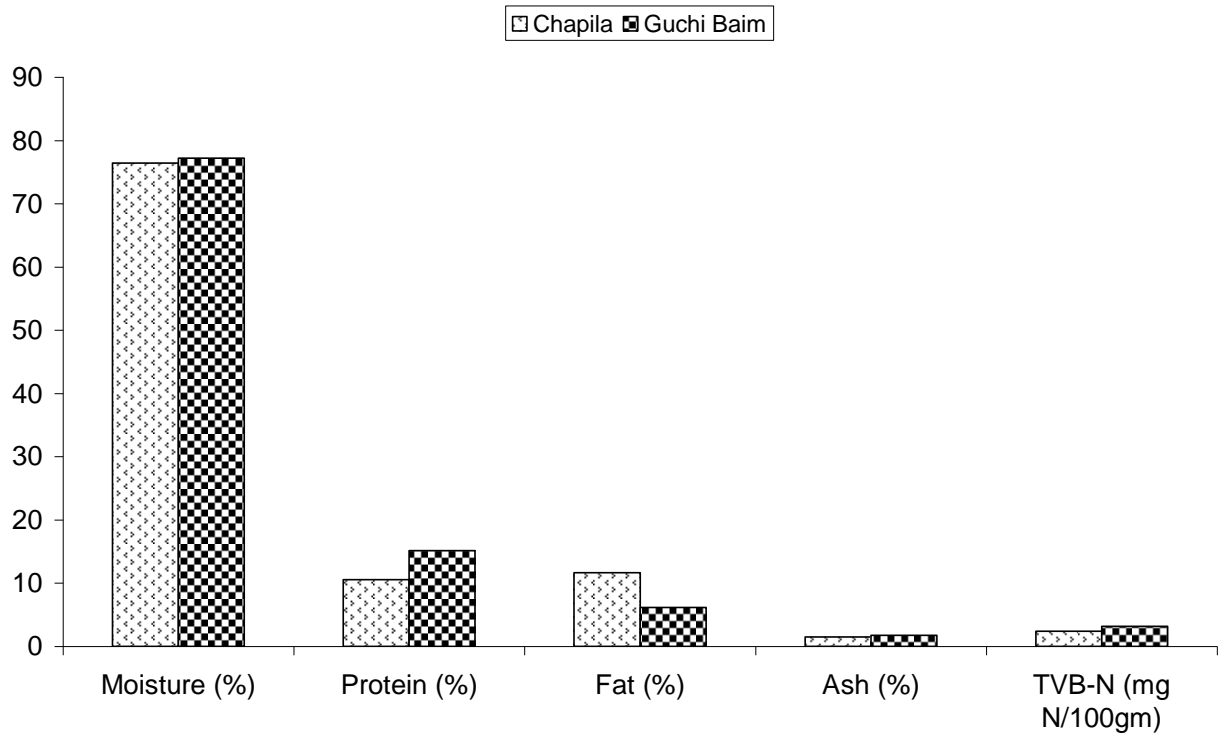

Figure 1. Changes in biochemical composition of fresh chapila and Guchi Baim fish.

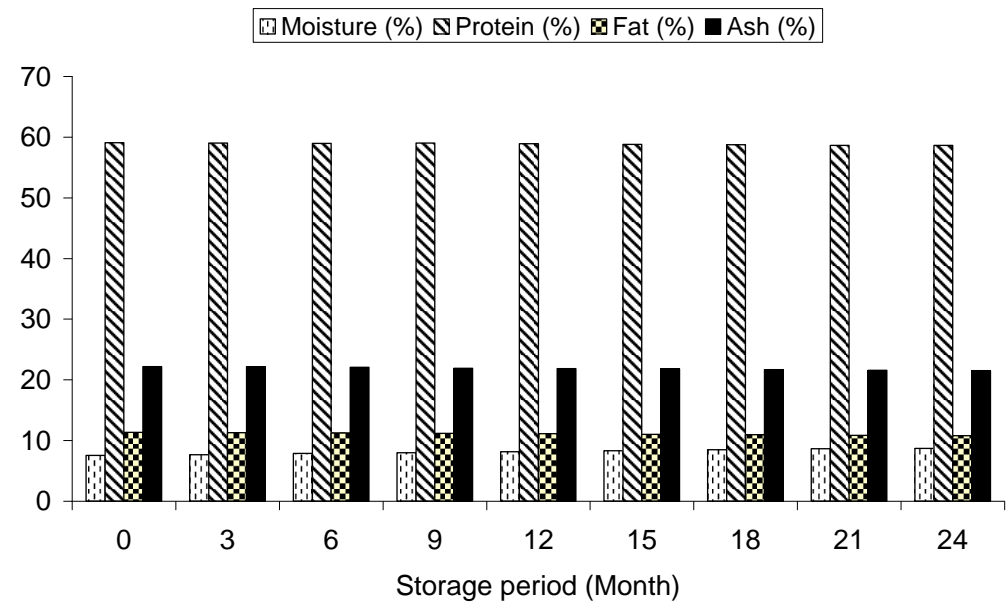

Figure 2. Changes in Proximate Composition of salt and garlic $(\mathbf{S}+\mathbf{G})$ treated smoke-dried Chapila fish during Storage at refrigerator temperature $\left(4^{0} \mathrm{C}\right)$.

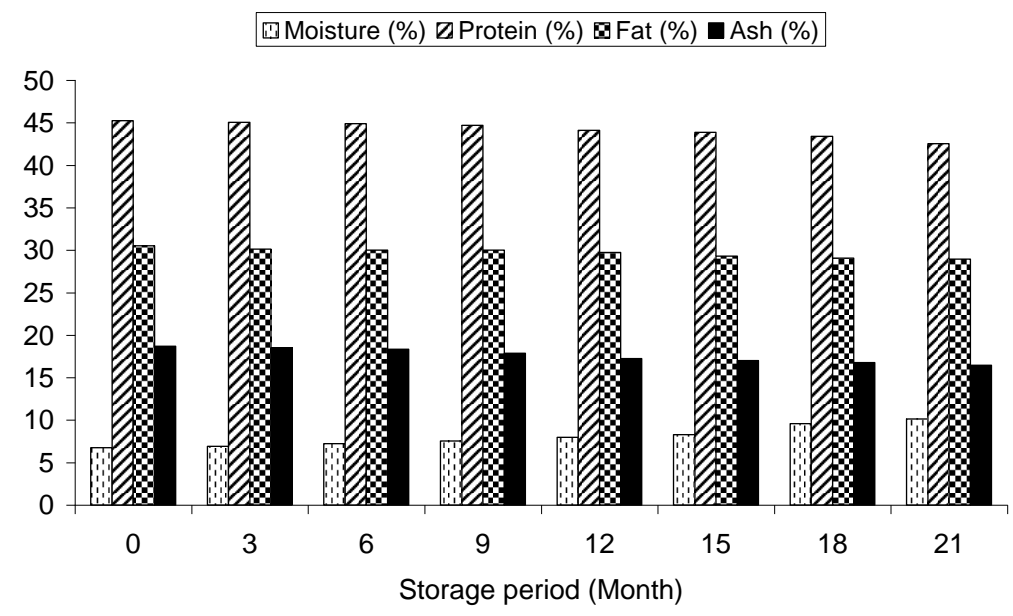

Figure 2. Changes in Proximate Composition of salt and garlic $(\mathbf{S}+\mathbf{G})$ treated smoke-dried Guchi-Baim fish during storage at refrigerator temperature $\left(4^{0} \mathrm{C}\right)$. 


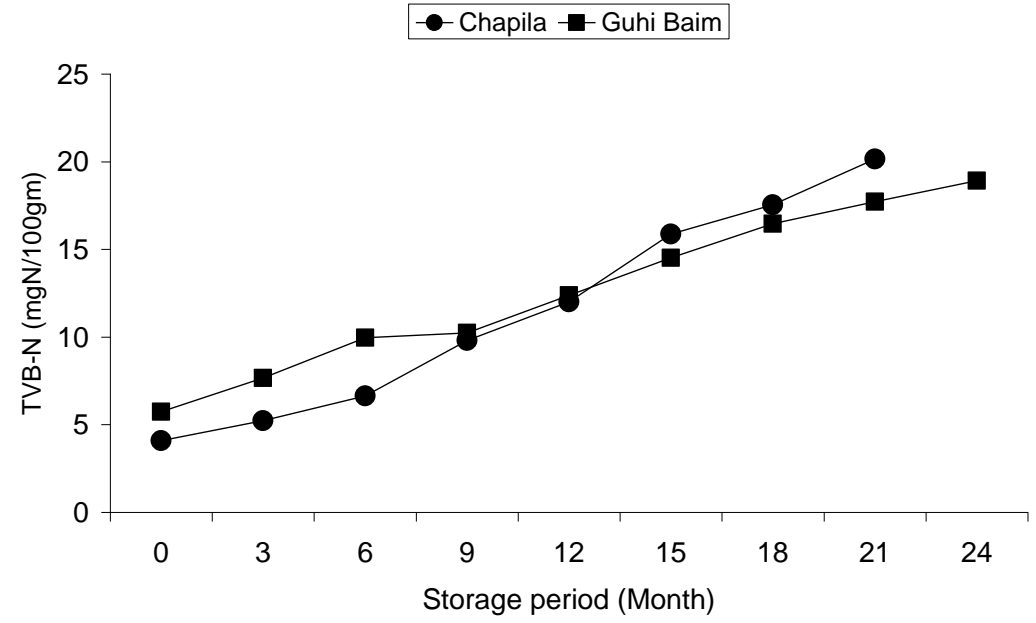

Figure. 4. Changes in TVB-N value of salt and garlic $(S+G)$ treated smoke-dried Chapila and GuchiBaim fish during storage at refrigerator temperature $\left(4^{0}\right)$. 